\author{
V International Forum on Teacher Education
}

\title{
Pedagogical Education in Russia: Current State, Experience, Outlook, Problems
}

\author{
Alexey Vladimirovich Lubkov*(a), Olga Alexandrovna Morozova (b)
}

(a), (b)Moscow Pedagogical State University, Moscow, Russia

\begin{abstract}
The relevance of the study of modern problems of pedagogical education in Russia is related to a number of factors. They are social factor (a prevalent opinion about the benefit of communication in network formats that are built on horizontal connections while ignoring vertical. Such formats are associated with reflexive experiences of a person's actions, elimination of borders due to their increasingly virtual nature and leveling responsibility for one's communicative actions in the Internet environment), philosophical factor (postmodernist ideas about an individual's imaginary freedom from the experience of the past, about a new technogenic man, not burdened with traditional views on life, values and morality) and economic factor (strengthening connections between education and services that divide training and education, reducing the purpose of education solely to transferring skills which detrimentally affects human and national qualities). In this regard, the purpose of this article is to identify and describe the current state and problems of pedagogical education in Russia, challenges that the modern technocratic society imposes on pedagogical education, prospects and vectors for its further development. The study employed the following methods: analysis of scientific sources, independent assessments, observation, and modeling.
\end{abstract}

Keywords: pedagogical education; prospects of educational development; subject's fundamental nature; system; practice-oriented approach; cultural and axiological components of education.

(C) 2019 Alexey Vladimirovich Lubkov, Olga Alexandrovna Morozova

This is an open access article distributed under the terms of the Creative Commons Attribution License (CC BY 4.0), which permits unrestricted use, distribution, and reproduction in any medium, provided the original author and source are credited.

Published by Kazan Federal University and peer-reviewed under responsibility of IFTE-2019 (V

International Forum on Teacher Education) 


\section{Introduction}

Moscow Pedagogical State University motto "Loyal to traditions, open to innovations" reflects the focus of pedagogical education on combining principles that take into account Russia's unique civilization course, traditional pedagogical foundations, new best pedagogical practices, and digital technologies.

The concept of education is timeless, as it retains its relevance in each era of our history, and pedagogical education as its branch, is designed to train future teachers while based on leading scientific and social paradigms, has always caused controversy, even absurd ideas about its redundancy, although the purpose of other branches of education (medical, military, economic, technological, etc.) has almost never been questioned.

For a balanced reaction on the changes that the future brings, it is important to understand the present. In order to be able to reflect on the present and identify the current problems, it is necessary to make a retrospective analysis of the process, its achievements, and mistakes. Pedagogical education can be regarded as a phenomenon of Russian culture. Its history is full of ups and downs: the first teacher's seminary was opened in Russia in 1786, then it became the Main Pedagogical Institute, and in 1819 St. Petersburg University emerged from it. After the Decembrist uprising of in 1825, the need for pedagogical personnel transmitting the state ideas arose again, so in 1828 the Main Pedagogical Institute was restored to be closed again in 1858. In the 1870s various teacher training courses started to emerge. So in 1872 in Moscow were opened Women's Courses of Higher Education, which were transformed into the Second Moscow State University in 1918, and later into the Moscow Pedagogical State Institute (now the Moscow Pedagogical State University). During the 19th and 20th centuries, pedagogical education was either placed at the forefront at the center or rejected. Special pedagogical educational institutions were created later to be transformed into classical universities, reflecting historical stages of stability or crises. In the most favorable periods for cultural and social development, pedagogical education was in demand, and the teaching profession was one of the most prestigious; in times of recession the importance of pedagogical education was leveled, and the teaching position lost its status. At the end of the $20^{\text {th }}$ debates about the role of pedagogical education were especially heated: an idea of the necessity of special teachers' training collided with an idea that anyone with higher education was capable of conducting the pedagogical activity. In the $21^{\text {st }}$ century, these disputes continue. Today higher pedagogical education still is a subject of fierce debates at various conferences, symposia, and forums. Teachers' role is also being re-evaluated, due to the rapid development of digital technologies, artificial intelligence, and robotics, which, according to some representatives of non-pedagogical professions, can soon replace a teacher by transferring educational process from a classroom to a virtual environment. Those who approve of it accuse education of being oriented only at the transfer of knowledge, which, in their opinion, a machine can easily do as well. However, computer technologies are only able to transfer information, not to organize effective transition from mastering through assimilation to appropriation, they are not adapted to respond to a child's misunderstanding, deliver information in different ways, through associations, building bridges to future knowledge, implementing L. Vygotsky's (2012) ideas about the zones of student's development. At the same time, capacities of learning environments and interactive assignments in many respects both motivate students and contribute to their training. Therefore a targeted study of the positive and negative aspects of the process of digitalization of education is necessary.

\section{Modern Tendencies}

The main widely recognized trends of modern vocational education are creativity, critical 
thinking, communication, cooperation, digitalization. It is essential to add the following traditional Russian educational values to the list: substantive fundamentality, systematic approach, practice-oriented approach, strengthening cultural and axiological components of education, development of national traits and human qualities, in order to achieve a synthesis of national and cultural traditions of Russian education with an innovative vector of development of the country (Nikandrov, 1995).

Traditions are the foundations of any innovation (Kiselev, Lubkov, \& Pahomov, 2019). Innovations that do not rely on time-tested theories are doomed to fail. Taking into account errors identified by time and correcting them is a pledge of a solid foundation for knowledge, a warning of a wrong and vicious path. Mistakes of the past teach us what to follow and what to avoid. As O. Wilde (2008) correctly stated that experience "is merely the name men gave to their mistakes". Hence, an intellectual and emotional reflection of experience is necessary to prevent future mistakes. One of the pressing issues of modern education is, on the one hand, development of new scientific and professional fields, and on the other, preservation of sovereignty and relevance of the professional niches traditionally respected by society.

There are a number of arguments for making teacher education a separate institutional component of vocational education. Pedagogical education is aimed at training personnel for a special professional field - it is an educational system, recognized as a separate science since antiquity. Philosophers and public figures always recognized the profession of a teacher as "[t]he most important thing in the world" (Likhachev, 2000, p. 89). Pedagogical education is a fusion of various sciences in which the sciences of man predominate (psychology, physiology) and the methods of its training (methodology, pedagogy) through various subject areas. The profession of a teacher is different from many professions in terms of the creative and cognitive components, since "to teach someone else you need more intelligence than to teach yourself" (M. Montaigne). For a teacher his subject is not a set of separate topics, which, undoubtedly, a person with a higher education, who does not have pedagogical training, can well and competently pass on to children, but a systemic pedagogical unity and the opportunities that arise from it, not only for learning but also for children's upbringing and development. A qualified teacher is able to deduce not only scientific laws but also values, that are much more important for children than just knowledge. This thought was expressed by Disterveg (1956, p. 31) who believed that "a teacher, his way of thinking is the most important thing in any training and upbringing," and only pedagogical environment can form such a teacher.

A number of objective parameters prove that pedagogical education should be taught only in pedagogical universities, and not in classical universities. First, the main task of classical universities is the training of science experts; students of such universities do not see themselves as future school teachers. Those who love teaching profession come to schools not from classical universities, but from teacher training institutions (Molodtsova, 2007).

Secondly, school teachers and teachers are representatives of one of the most popular professions. It has many requirements: empathy, kindness, justice, creativity, tolerance, etc. (as human qualities), methodology, pedagogy, psychology and others (as the basis of the teaching profession), proficiency in speech techniques, verbal and non-verbal behavior, etc. (as a condition for successful teaching activities), team-building, etc.; no other field of education is requires these qualities.

Thirdly, a classical university graduate who considers himself the intellectual elite will work in a village. Sometimes a rural school teacher has to teach several subjects at once; no classical university will prepare for this. 
Fourthly, classical universities will not prepare a preschool teacher and a primary school teacher, since these professions are built not so much on their subject, but on the interdisciplinary and meta-subject synthesis of knowledge from different areas.

Finally, teacher's work, first of all, suggests selflessness, assistance, absolute dedication, and active citizenship. Being a teacher is not so much a profession, it is a way of life. Becoming a teacher on one's own is almost impossible, becoming a teacher develops only in the pedagogical environment, which can be created by a pedagogical university.

Nowadays, undoubtedly, due to a rapid development of science, there is a need to introduce new technological content to pedagogical education, but the main goal of teacher professional training - a merge of teaching and upbringing, remains the same: formation of patriotism, spirituality, humanity and other qualities that will not ever change.

Only pedagogical education and its traditional values together with new tendencies is able to withstand technocracy by introducing artificial intelligence to the educational process. Teachers, psychologists, philosophers, and others recently have started to emphasize the need to develop alternative solutions to the problems of modern trends related to Internet communications that make imbalanced use of information possible. There the whole space is "one continuous text which is also a context, where the main goal is to exchange information and chaotically constructed discourse" (Keligov, 2012, p. 57). According to Ellul (2018), the technical sphere is capable of consuming a person and his or her imagination to a degree that the person cannot withdraw from it, so "he has to exist in this very moment, to rely on evidence, and act as if in a state of hypnosis" (Keligov, 2012, p. 57). These and other threats of the technological world (cyberbullying, cyber-trolling, etc.) require special teachers' training, especially in the field of pedagogical cybersecurity. In this day and age, digital literacy and digital ethics should be introduced to traditional teachers' training courses.

In recent publications ideas that the traditional pedagogical profession will not be in demand, that a teacher will be replaced by a coordinator of an online platform, a startup mentor, an environmentalist, a mind fitness instructor, and, eventually, a robot, have begun to appear more and more often. These ideas are utopian because the profession of a teacher is inherently connected with communication that no artificial intelligence would ever be able to do. It is a profession that requires such qualities as empathy, critical thinking, creativity, artistry, responsibility, ability to use metaphors, humor, instant reaction, equality, etc. All these qualities cannot be programmed; therefore a robot can never fully substitute a teacher.

Globalization which is regarded by many the main course of the development of the modern world leads to a number of deformations associated with homogenization and even possible destruction of national uniqueness because global values are prioritized, which sometimes contradicts national values. In the context of globalization, it is the teacher who opens a pedagogical dialogue based on the moral values and spiritual bonds of generations. Thus, a teacher should take on the role of preserving, strengthening and enhancing national, cultural and ethnic identity.

A teacher is always burdened with a special social mission, his high responsibility is to preserve and transform our national existence. Nowadays concepts of moral and immoral are becoming more and more blurred, this is why a teachers' role, his or her life, civil and moral priorities become more and more significant. A teacher can encourage a child in his search for beauty, goodness, and truth, in his way to God. These values are implicitly built into the educational process. A teacher's personal system of values may become a foundation of a student's axiological orientations. The matter is not only in teacher's talent 
but also in search of the organizational and substantive solution of a number of issues in education, which should be somewhat revised.

The task of the teacher is not to form a qualified consumer, a "perfect man" of the globalized world (even worse than superman who, according to Nietzsche, is deprived of moral qualities who despises the "lower class", characterized as "herd", "mass", "mob", which does not live according to the "higher" ideals), but in the upbringing of a citizen of his country, a patriot who remembers and lives accordingly to spiritual and moral principles, bequeathed by his ancestors. Thus, the main task of training a teacher is to teach the means of inculcating global and national humanistic values. New technology, being an instrument of upbringing and education, should not be a goal in itself, but serve as educational means.

Such teacher training is connected, on the one hand, with intensification of the learning process, familiarization with the latest educational ideas, and on the other - with training and developmental technologies, in other words, enriching psychological and pedagogical disciplines with theory and practice of working with children (the so-called digital natives), tools for neutralizing negative impact of internet communications. The strategic development of the country, its leadership in the technological and intellectual spheres largely depends on the synthesis of both directions. The main pedagogical goals should be related to the development of creativity in the future teachers who would be able to activate their own and their students 'cognitive and creative capabilities.

Creativity as an integral part of pedagogical activity should find the right place in pedagogical education. The teacher should be able to combine familiar elements in a new way, understand mechanisms of their transformation, select, replace and combine the elements and fully understand possibilities of the process. For example, when assembling Lego constructor with children at first one object (for example, a machine) and then another one (for example, a ship), a teacher should be able to foresee which elements can be used for the new object, what details are not enough and what can be replaced. The teacher should not only be a creative person but also be able to predict students' needs for finding non-standard solutions through original connections of familiar elements into a newly synthesized object. It is necessary to learn to reach beyond the familiar; a teacher by his example is able to inspire students, "to ignite the fire of knowledge in them", "to awaken the thirst for creativity". Digital technologies that are so appealing to today's children can be a doorway to the world of "wonderful discoveries", although this is possible only if the educational paradigm is correctly built by the teacher and does not lead to an anti-utopian "brave new world" (Huxley, 1998).

Modern technologies (including digital) are recognized today not only as tools for information search, but also as a condition of the possibility of cognition, which is transformed supersaturated information field, in which a person has to not only learn, work but also live a modern person. On the one hand, technologies make the flexible search for the necessary information possible, on the other hand, hybridization and interference of information flows, their mixing and shifting also takes place. Browsing different Internet pages often does not lead to holistic knowledge, it remains eclectic, mosaic, distorted (downloading, reproducing instead of creative reading and meanings). To neutralize these risks, it is necessary to introduce to a modern teacher's training new techniques and means of navigating a child's thinking in the appropriate direction, helping to master ways of learning, technologies of working with information, both at cognitive and technological levels.

Today a modern Russian teacher must have a high level of digital literacy (informational, computer, communicative, media literacy) in order to properly educate schoolchildren and to avoid possible risks. The main guideline may be to take into account the component of value, since 
communication with machines leads to the loss of human qualities, transformation of a man as a living organism into a set of functions and services that can only serve a narrow specter of specific needs, deteriorate communication skills, develop social autism and escapism. The main risk of abandoning humanistic ideals may be the transformation of Homo Sapiens into E-Homo, which may become a new stage in human evolution on the one hand, and, on the other to stop its existence as a biological species. Only human communication and interaction can counter this, and traditional pedagogical process, based on the pursuit of truth, is designed to preserve human identity in the digital space and the anthropocentricity of the world as a whole.

\section{Conclusion}

It is necessary to reconsider the content of teachers' training and to reinforce an educational picture of the world which is based on scientific knowledge and historical Russian experience of development, spiritual and moral aspects of life in the context of problems of modern civilization. It is also necessary to restore a broad cultural and historical approach to education as a special social institution for transmitting and preserving national values and traditions in the process of personality development.

It is crucial to abandon a consumerist approach to education and to substitute it with the traditional Russian understanding of education which is based on the following concepts: a Russian citizen, a patriot who is guided by spiritual and moral principles bequeathed by ancestors; socialization through real communication (as opposed to technocratic one) and development of traditional Russian personal qualities. A purely technological and technocratic approach to all levels of education based solely on techniques must be replaced by an interdisciplinary synthesis that systematically integrates various elements into a coherent unity. Restoration of social and professional prestige should be the foundation for preservation and development of the national system of pedagogical education.

MPGU traditionally educated not only Russian teachers but also foreign ones, in particular, teachers of the countries of the Commonwealth of Independent States (CIS). Therefore in 2018, the University was the CIS host for teachers' training, which showed the necessity to conduct additional comparative research in the field of pedagogical education in a number of countries. The aforementioned problems need to be addressed throughout the post-Soviet space. It is necessary to bring back a personal aspect to education so that our national culture and our national education system could be reunited.

The foundation of pedagogical education should be a teacher who has a broad outlook, erudition and established a system of values and cultural traditions. If in pursuit of technology, we forget the main thing - a person, then we will never be able to keep up with any technology.

\section{References}

Disterveg, A. (1956). Izbrannye pedagogicheskie sochineniya [Selected pedagogical works]. Moscow: Akademia.

Ellul, J. (2018). The technological system. Eugene: Wipf and Stock Publishers.

Huxley, A. (1998). Brave New World. 1932. London: Vintage.

Keligov, M. Y. (2012). Homo sapiens: transient phenomenon. Moscow: Akademia.

Kiselev, A., Lubkov, A., \& Pahomov, N. (2019). Obrazovanie v perspective antropologitseskogo perehoda (pedagogitseskaua utopiya dlya XXI veka) [Education in the perspective of anthropological changes (pedagogical utopia for XXI century)]. Vischee ovrazovaniye segodnya, 76-83. 
Likhachev, D. S. (2000). Reflections on the Russian soul: a memoir. Budapest: Central European University Press.

Molodtsova, V. (2007). Protivostoyanie: pedvuz ili universitet. Kto pobedit v konkuretnoy borbe [Resistance: teacher training or non-pedagogical university. Who won in the competitive struggle?]. Universitetskaya gazeta, 42-54.

Nikandrov, N. D. (1995). Russian education after perestroika: the search for new values. International review of education, 41(2), 47-57.

Vygotsky, L. S. (2012). The collected works of LS Vygotsky: Scientific legacy. London: Springer Science \& Business Media.

Wilde, O. (2008). The Picture of Dorian Gray. Oxford: Oxford World's Classics. 